\title{
Arch bridge made of reactive powder concrete
}

\author{
D. Cizmar ${ }^{1}$, D. Mestrovic ${ }^{2} \&$ J. Radic ${ }^{2}$ \\ ${ }^{1}$ Ekonerg Institute, Zagreb, Croatia \\ ${ }^{2}$ Faculty of Civil Engineering, University of Zagreb, Zagreb, Croatia
}

\begin{abstract}
Concrete is the most commonly used building material. It is used for buildings, industrial structures, bridges and dams. Every day the concrete is being improved, to achieve better characteristics, reduce price and to be environmental acceptable. In the introduction an historical overview of concrete is given beginning in the $1950 \mathrm{~s}$ when the compression strength was $40 \mathrm{~N} / \mathrm{mm} 2$. Today this is the Industry standard. Concrete with compression strength greater than 40 $\mathrm{N} / \mathrm{mm} 2$ is called high performance concrete (HPC). The first HPS concretes were made in 1960. Around 1990, Reactive Powder Concrete (RPC) started to appear. Their strengths go up to $800 \mathrm{~N} / \mathrm{mm}^{2}$. Today, HPC is limited to bridges, and RPC is still very rarely used. In this work we present a method for making a RPC composite material with a compression strength of up to $170 \mathrm{~N} / \mathrm{mm}^{2}$. Preparation and testing of material is performed in the laboratory of the Faculty of Civil Engineering in Zagreb. In addition to the mechanical properties, the durability parameters are also tested. Detailed concrete mix proportions are given in the article. The possibility that RPC could be used to construct an arch bridge over Bakar strait (Croatia) is analyzed. The bridge would have arch span of 432 $\mathrm{m}$. Due to very high compression strength of RPC the span length may be increased, therefore reducing the total construction cost. RPC is also used to increase the resistance to freeze-thaw cycles, increase abrasion resistance, and reduce chloride permeability. Many large Adriatic bridges have experienced durability problems that are primarily the result of using standard concrete. Each of these durability enhancements provided by RPC decrease maintenance costs and lengthens the service life of a structure, which is vital for bridges in the Adriatic region.
\end{abstract}

Keywords: arch bridge, reactive powder concrete (RPC), construction technology. 


\section{Introduction}

Cement is around 12 millions years old. Reactions between limestone and oil shale during spontaneous combustion occurred in Israel to form natural deposits of cement compounds. The deposits were first described by Israeli geologists between 1960 and 1970. In 3000 years BC, the Egyptians used mud mixed with straw to bind dried bricks. They also used gypsum mortars and mortars of lime in the construction of the pyramids. Chinese used cementitious materials to hold bamboo together in their boats and in the Great Wall of China. The Romans used pozzolana cement from Pozzuoli, Italy near Mt. Vesuvius to build the Appian Way, Roman baths, the Coliseum and Pantheon in Rome, and the Pont du Gard aqueduct in southern France. They used lime as a cementitious material. Pliny reported a mortar mixture of 1 part lime to 4 parts sand. Vitruvius reported a 2 parts pozzolana to 1 part lime mixture. Animal fat, milk, and blood were used as admixtures (substances added to cement to improve properties).

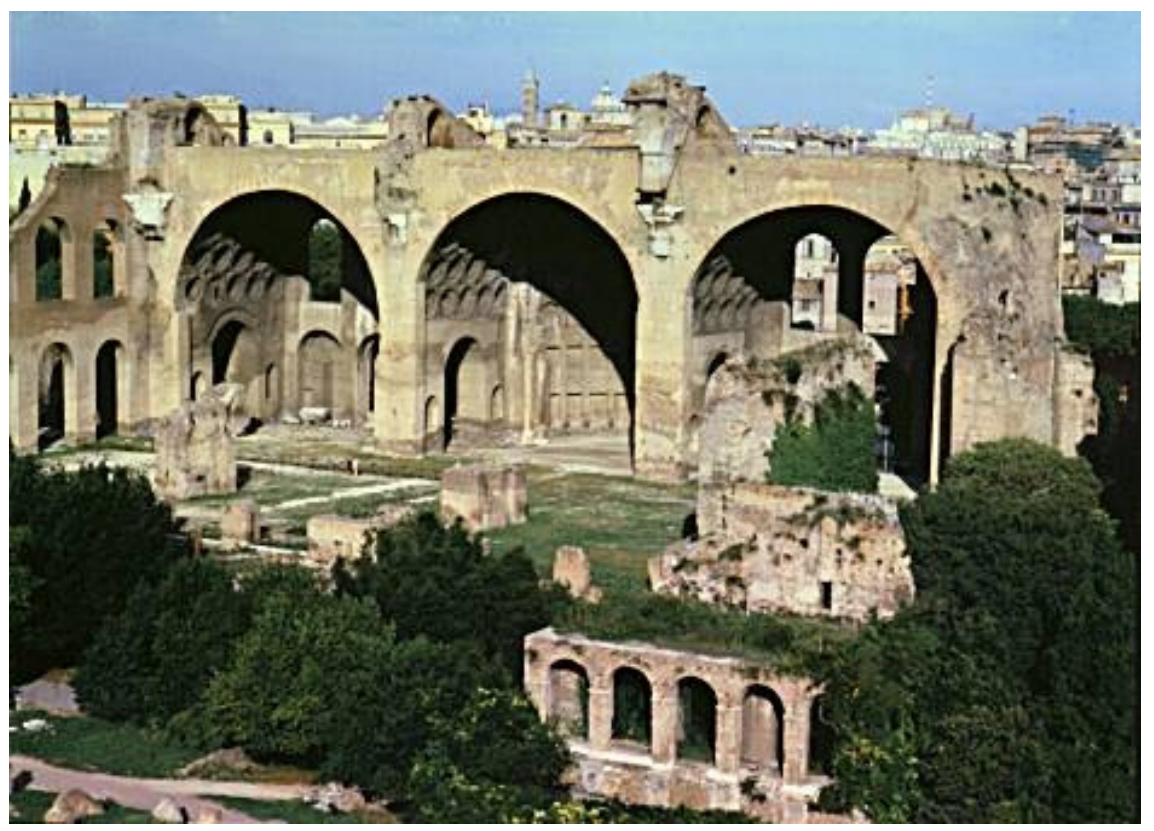

Figure 1: Maxentius basilica.

Fig. 1 shows the Maxentius basilica built in the $4^{\text {th }}$ Century. These materials were not used again until the beginning of the $19^{\text {th }}$ Century. In 1824, Joseph Aspdin of England invented Portland cement by burning finely ground chalk with finely divided clay in a lime kiln until carbon dioxide was driven off. The sintered product was then ground and he called it Portland cement named after the high-quality building stones quarried at Portland, England. Portland cement started the era of modern composition cements. In 1828, I. K. Brunel made the 
first significant engineering application of Portland cement, using it to fill a breach in the Thames Tunnel. In 1867, Joseph Monier of France reinforced William Wand's (USA) flower pots with wire ushering in the idea of iron reinforcing bars (re-bar). In 1889, the first concrete reinforced bridge was built. Around 1950, concrete with a compression strength of $40 \mathrm{~N} / \mathrm{mm}^{2}$ was made. In the 1960's, High Performance Concrete (HPC) was made. HPC is the name given to a class of materials that exhibits properties superior to those of conventional concrete. The superiority may lie in one or more of several attributes, such as strength, stiffness, freeze-thaw durability, or resistance to chemical attack. The properties are selected on the basis of the requirements of the particular application. Its compression strength ranges from the $50 \mathrm{~N} / \mathrm{mm}^{2}$ to $100 \mathrm{~N} / \mathrm{mm}^{2}$. In the 1970 's, fiber reinforcement in concrete was introduced. During the 1980's, superplasticizers were introduced as admixtures. Around 1990, Reactive Powder Concrete (RPC) appeared. Their compression strength goes up to $800 \mathrm{~N} / \mathrm{mm}^{2}$. While HPC is increasingly used for bridges, RPC is still very rarely used.

\section{Components for RPC mixture}

\subsection{Introduction}

This article presents the possibility of making RPC concrete with compression strengths up to $200 \mathrm{~N} / \mathrm{mm}^{2}$. Four different mixtures are analyzed. The first is mixture of hybrid micro-fiber concrete; the others are composed of only one type of fibers.

\subsection{Cement}

As the class of cement increases the compression strength increases. For this mixture we have selected the Portland cement PC 55 with no mineral ingredients.

\subsection{Fine aggregate}

Aggregate that is used for the making of this mixture is quartz aggregate. Two fractions of this material are used: one with soil size of $0.125-0.25 \mathrm{~mm}$, other with $0.25-0.5 \mathrm{~mm}$, This effectively means that maximal soil size is $0.5 \mathrm{~mm}$.

\subsection{Steel fibers}

Two different types of steel fibers are used (shorter and longer fibers). Shorter fibers are $13 \pm 2 \mathrm{~mm}$ long, diameter is $0.2 \pm 0.02 \mathrm{~mm}$. Minimal tensile strength is $2600 \mathrm{MPa}$. Longer fibers have curved ends; their length is $40 \pm 3 \mathrm{~mm}$ and diameter $0.5 \pm 0.02 \mathrm{~mm}$. Minimal tensile strength is $2600 \mathrm{Mpa}$. In both cases, the high tensile fibers are used to achieve necessary ductility.

\subsection{Silica fume}

Silica fume is a pozzolanic additive, with specific area of $20 \mathrm{~m}^{2} / \mathrm{g}$. 
Other parameters are:

- density

- sieve residue

- $\mathrm{pH}$ value

$45 \mu \mathrm{m}$

$2.23 \mathrm{~g} / \mathrm{cm}^{3}$

$5.6 \%$

8.44

\subsection{Superplasticizer}

Superplasticizer is primary used to decrease the participation ratio of water in the concrete mixture. Chosen superplasticizer is based on policarbon-silate. It is a brown fluid, dissolves in water and doesn't contain chlorides.

Other parameters are:

- density

- pH value

$1.064 \mathrm{~kg} / \mathrm{dm}^{3}$

- alkalinity

7

- viscosity on $20^{\circ} \mathrm{C}$

$0.31 \%$

$134 \mathrm{mPas}$

Table 1: $\quad$ Ingredients per $\mathrm{m}^{3}$ of RPC.

\begin{tabular}{|c|c|c|c|c|}
\hline Mixture number & M1 & M2 & M3 & M4 \\
\hline $\begin{array}{l}\text { Steel fibers } \\
\left(\mathrm{kg} / \mathrm{m}^{3}\right) \\
\text { SF1 }(40 / 0.5) \\
\text { SF2 }(13 / 0.2)\end{array}$ & $\begin{array}{c}76 \\
190\end{array}$ & 228 & 228 & 234 \\
\hline Cement $\left(\mathrm{kg} / \mathrm{m}^{3}\right)$ & 720 & 955 & 720 & 980 \\
\hline $\begin{array}{l}\text { Fine aggregate } \\
\left(\mathrm{kg} / \mathrm{m}^{3}\right)\end{array}$ & 230 & 239 & 230 & 303 \\
\hline $\begin{array}{l}\text { Quartz sand } \\
0.125-0.25 \\
0.25-0.5 \\
\left(\mathrm{~kg} / \mathrm{m}^{3}\right)\end{array}$ & $\begin{array}{c}123 \\
1112\end{array}$ & $\begin{array}{l}105 \\
945\end{array}$ & $\begin{array}{c}123 \\
1111\end{array}$ & $\begin{array}{l}105 \\
965\end{array}$ \\
\hline $\begin{array}{l}\text { Superplasticizer } \\
\left(\mathrm{kg} / \mathrm{m}^{3}\right)\end{array}$ & 30 & 35 & 31 & 40 \\
\hline Water $\left(1 / \mathrm{m}^{3}\right)$ & 190 & 215 & 190 & 209 \\
\hline $\begin{array}{l}\text { Concrete } \\
\text { properties } \\
\text { temperature } \\
\text { pores } \\
\text { density } \\
\text { consistency }\end{array}$ & $\begin{array}{c}24^{\circ} \mathrm{C} \\
5 \% \\
2.41 \mathrm{~kg} / \mathrm{m}^{3} \\
140 \mathrm{~mm}\end{array}$ & $\begin{array}{c}25^{\circ} \mathrm{C} \\
5 \% \\
2.35 \mathrm{~kg} / \mathrm{m}^{3} \\
250 \mathrm{~mm}\end{array}$ & $\begin{array}{c}24.5^{\circ} \mathrm{C} \\
5 \% \\
2.36 \mathrm{~kg} / \mathrm{m}^{3} \\
190 \mathrm{~mm}\end{array}$ & $\begin{array}{c}26^{\circ} \mathrm{C} \\
5 \% \\
2.306 \mathrm{~kg} / \mathrm{m}^{3} \\
220 \mathrm{~mm}\end{array}$ \\
\hline
\end{tabular}




\subsection{Compatibility of cement and superplasticizer}

The compatibility of PC 55 cement and superplasticizer Glenium ACE 30 is one of the important requirements for achieving a good RPC mixture. Compatibility is measured by a change in the consistency of the concrete. To achieve proper treatment of concrete it must retain its characteristics for approximately $1.5 \mathrm{~h}$ for site application and $0.5 \mathrm{~h}$ for prefabrication.

\section{Experimental results}

Compression and tensile strength measurement were conducted on four specimens with a prismatic shape $(40 \times 40 \times 160 \mathrm{~mm})$. The specimens were 28 days old. First, the tensile strength was measured, then the compression strength. Table 2 presents the experimental results for each mixture. Fig. 2 shows the specimens after the tests.

Table 2: $\quad$ Experimental results.

\begin{tabular}{|c|c|c|}
\hline & $\begin{array}{l}\text { Flexure strength (mean) } \\
(\mathrm{MPa})\end{array}$ & $\begin{array}{l}\text { Compression strength (mean) } \\
(\mathrm{MPa})\end{array}$ \\
\hline M1 & 46.9 & 132.0 \\
\hline M2 & 42.8 & 155.6 \\
\hline M3 & 42.8 & 153.3 \\
\hline M4 & 48.8 & 174.8 \\
\hline
\end{tabular}

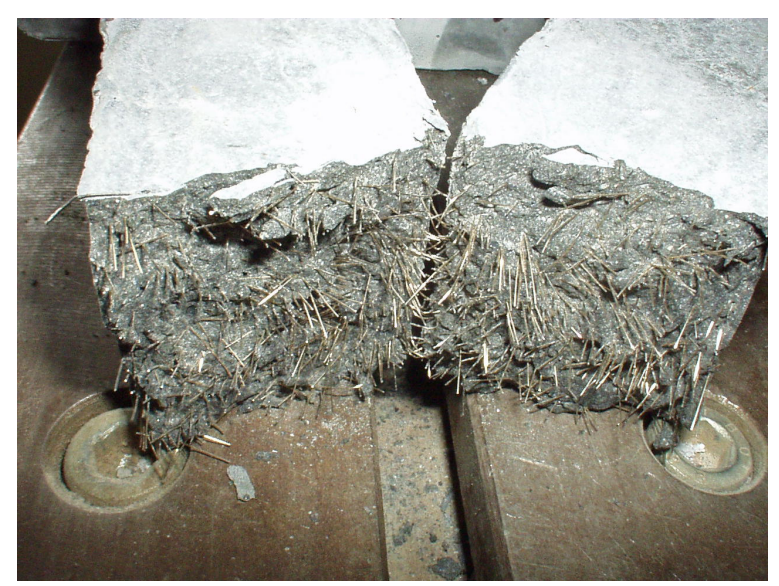

Figure 2: Specimens after testing.

\section{Gas permeability test}

Gas permeability is tested according to Croatian regulations EN 993-4. Specimens were cylindrical, the diameter and length were $50 \mathrm{~mm}$. They were taken from a $10 \times 10 \times 50 \mathrm{~cm}$ prism (first mixture). The specimens were put in 
dry chamber until constant mass was achieved. The specimens were than cooled to room temperature, polished and coated with epoxy. A pressure difference of 3 bars wasn't detected, which means that gas permeability should have been very low (none was detected).

\section{Capillary water test}

A capillary water test is conducted according to Croatian regulations HRN.U.M8.300:1985 in the laboratory of the Civil engineering faculty in Zagreb on specimens 28 days old. The diameter of the specimen was $15 \mathrm{~cm}$ and hadd a height of $10 \mathrm{~cm}$. Before test the specimens are dried on $105^{\circ} \mathrm{C}$ and then left for 2 days in laboratory. Sealing putty is applied on one side. Specimens are then weighed.

The capillary water test was performed in intervals of $1,3,5,10,15$, and 30 minutes after immersing in water, and then after 1, 2, 3, 4, 5, 6, and 24 hours. Results show the linear proportion between the capillarity water and square root of time. The height of capillarity water could not be determined because it didn't cross the area sealed with sealing putty. The starting absorption capacity for ordinary concrete is $0.25 \mathrm{ml} / \mathrm{m}^{2} / \mathrm{s}$ after $10 \mathrm{~min}, 0.17 \mathrm{ml} / \mathrm{m}^{2} / \mathrm{s}$ after $30 \mathrm{~min}$, and $0.10 \mathrm{ml} / \mathrm{m}^{2} / \mathrm{s}$ after 1 hour. These results show (table 3 ) that RPC has very little water permeability. Its absorption after 10 minutes is much lesser than that of ordinary concrete after an hour.

Table 3: $\quad$ Capillary water test.

\begin{tabular}{|l|l|l|l|}
\hline Time & $\begin{array}{l}\text { A sample } \\
\left(\mathrm{kg} / \mathrm{m}^{2} / \mathrm{s}\right)\end{array}$ & $\begin{array}{l}\text { B sample } \\
\left(\mathrm{kg} / \mathrm{m}^{2} / \mathrm{s}\right)\end{array}$ & $\begin{array}{l}\text { C sample } \\
\left(\mathrm{kg} / \mathrm{m}^{2} / \mathrm{s}\right)\end{array}$ \\
\hline $0 \mathrm{~min}$ & 0 & 0 & 0 \\
\hline $1 \mathrm{~min}$ & 0.000613 & 0.000754 & 0.00066 \\
\hline $3 \mathrm{~min}$ & 0.00029 & 0.000306 & 0.000291 \\
\hline $5 \mathrm{~min}$ & 0.00022 & 0.000212 & 0.000198 \\
\hline $10 \mathrm{~min}$ & 0.000122 & 0.000122 & 0.000117 \\
\hline $15 \mathrm{~min}$ & 0.000089 & 0.0000896 & 0.0000864 \\
\hline $30 \mathrm{~min}$ & 0.0000526 & 0.0000518 & 0.0000511 \\
\hline $1 \mathrm{~h}$ & 0.0000314 & 0.0000310 & 0.0000302 \\
\hline $2 \mathrm{~h}$ & 0.0000182 & 0.0000181 & 0.0000176 \\
\hline $3 \mathrm{~h}$ & 0.0000133 & 0.0000133 & 0.0000131 \\
\hline $4 \mathrm{~h}$ & 0.0000105 & 0.0000107 & 0.0000103 \\
\hline $5 \mathrm{~h}$ & 0.00000888 & 0.00000888 & 0.00000864 \\
\hline $6 \mathrm{~h}$ & 0.00000451 & 0.00000451 & 0.00000439 \\
\hline $24 \mathrm{~h}$ & 0.00000242 & 0.00000251 & 0.00000241 \\
\hline
\end{tabular}

\section{Bridge over Bakar strait}

We will now explore the possibility that a future arch bridge over Bakar strait could be made of RPC. By building this bridge the highway would be $7 \mathrm{~km}$ 
shorter. The bridge arch span would be $423 \mathrm{~m}$, vertical clearance is $72 \mathrm{~m}$. Bridge has 22 piers (spans are $30+20 \times 38+30 \mathrm{~m}$ ). Fig. 3 represents the longitudinal section of the bridge. A cross section of the bridge is shown on fig. 4 . The cross section is constant and aerodynamic. With the exception of the foundations, abutments, and highest piers, the whole bridge will be build from pre-cast segments $3.8 \mathrm{~m}$ long. To achieve symmetric load bearing structure will be supported from both sides. Segments that weight $718 \mathrm{kN}$ are being composed and pre-stressed in pressurising station behind the abutments and then pushed. Computer simulation of the Bakar bridge is presented in fig 5.

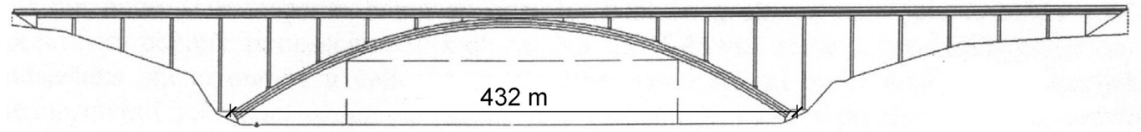

Figure 3: Longitudinal section of the bridge.

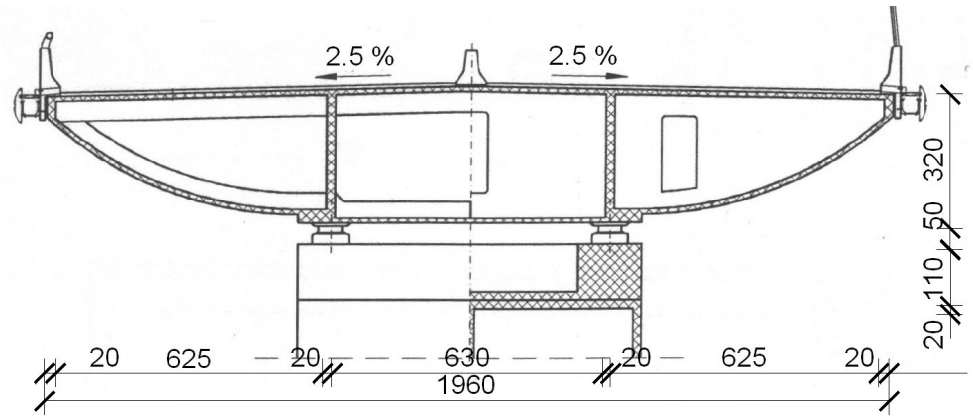

Figure 4: $\quad$ Cross section of the bridge.

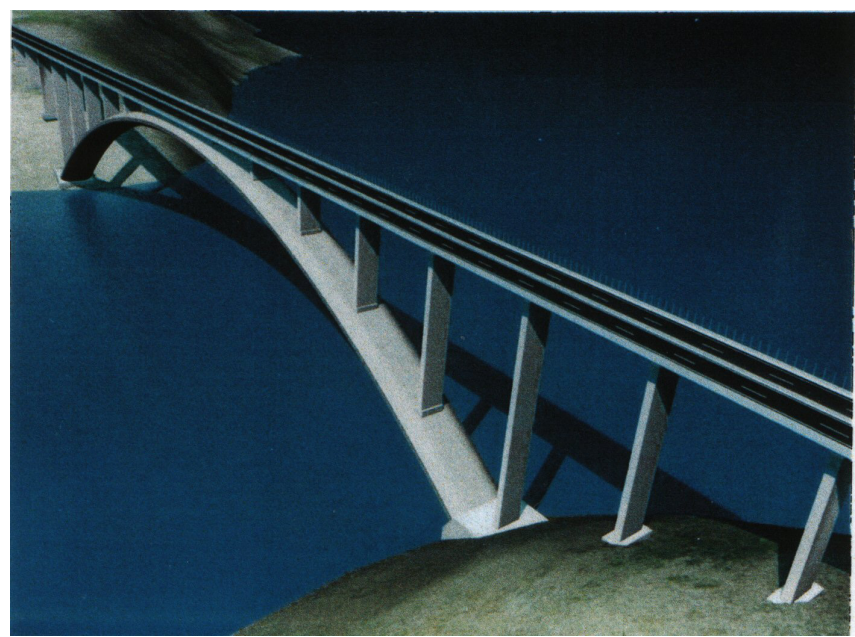

Figure 5: $\quad$ Computer simulation of the bridge. 


\section{Basic design}

Calculations are made for stresses during usage, strains during construction, stresses and strains of bearing structure during construction and usage. With the exception of dead and traffic load these calculations cover temperature load, creep, lateral wind, and earthquake load. Table 4 shows maximal stresses for each part of the bridge. Road slab and transverse beams are the only parts of the structure where tensile stresses are about $15 \mathrm{MPa}$. Due to very high stresses, passive reinforcement with ropes will be used. In transverse beams internal prestressing with addition of passive reinforcement will be used. This conception is not very often with RPC and in future phases of the project it should be carefully considered.

Table 4: $\quad$ Maximal stresses.

\begin{tabular}{|c|c|c|}
\hline Part of structure & Maximal compression (Mpa) & Maximal tension (Mpa) \\
\hline Road slab & 15.30 & 15.30 \\
\hline Transverse beam & 10.24 & 15.50 \\
\hline Highest pier & 15.36 & 6.92 \\
\hline Arch & 67.35 & 10.61 \\
\hline
\end{tabular}

\section{Conclusion}

In this article we have presented the possibility that a future arch bridge over the Bakar strait (Croatia) could be made from RPC. Due to the very high compression strength of RPC it can be used for large spans. RPC also has superb durability parameters as well as a high abrasion resistance and reduced chloride permeability. This makes RPC an ideal material for bridges on the Adriatic cost because durability problems are primary related to the fact that the reinforcement's protective layer is rapidly being destroyed. Winds that reach up to $250 \mathrm{~km} / \mathrm{h}$ drift large amounts of chlorides that destroy the bridge structure, primary the arch and the columns. Each of these durability enhancements provided by RPC decrease maintenance costs and lengthen the service life of a structure, which is vital for bridges in the Adriatic region.

\section{References}

[1] Candrlic, V., Concrete arch bridge over Bakar straits. Proceedings for Conference of Croatian builders, eds. V. Simovic, Cavtat, pp. 358-364, 2001.

[2] Jagar, A., High performance concrete, Faculty of civil engineering: Zagreb, 2003. 
[3] Mrakovcic, S., Precast arch bridges made of reactive of powder concrete, Faculty of civil engineering: Zagreb, 2001.

[4] Edward Nawy, G., Fundamentals of high-performance concrete, John Wiley \& Sons: New York, 2001. 